\title{
Results of Surgical Treatment of Uncomplicated Colon Cancer. Case Series with Follow-Up
}

\author{
Resultados del Tratamiento Quirúrgico del Cáncer de Colon no Complicado. \\ Serie de Casos con Seguimiento
}

Carlos Manterola ${ }^{1,2} \&$ Nataniel Claros $^{3}$

\begin{abstract}
MANTEROLA, C. \& CLAROS, N. Results of surgical treatment of uncomplicated colon cancer. Case series with follow-up. Int. J. Morphol., 39(4):1171-1175, 2021.

SUMMARY: The standard treatment of colonic cancer $(\mathrm{CC})$ continues to be the radical resection of the intestinal segment compromised with free margins, associated or not with adjuvant therapies. The aim of this study was to determine postoperative morbidity (POM) and 5-year overall survival (OS) in patients with uncomplicated colon cancer surgically treated. Retrospective case series of patients with uncomplicated CC undergoing colectomy and lymphadenectomy, consecutively, at Clínica Red Salud Mayor Temuco, between 2007 and 2019. The outcomes variable were POM and 5-years OS. Other variables of interest were surgical time, number of resected lymph nodes, hospital stay and recurrence. Descriptive statistics was used (measures of central tendency and dispersion), and OS analysis was applying Kaplan Meier curves. In this study, 52 patients (53.8\% men) were intervened, with a median age of 68 years. The most frequent localization and stages were right colon (42.3\%); IIIA and IIIB respectively (78.9\%). Median surgical time, number of resected lymph nodes and hospital stay were $98 \mathrm{~min}, 34$ and 4.5 days respectively. POM was $17.3 \%$ ( 9 cases). With a median followup of 58 months, a recurrence of $19.2 \%$ was verified, and the 5-year OS for stages IIA, IIIA, IIIB and IVA was $83.3 \%, 73.6 \%, 68.2 \%$ and $40.0 \%$ respectively. The results, in terms of POM, mortality and 5-year OS, were similar to national and international series.
\end{abstract}

KEY WORDS: Colonic Neoplasms; Colonic Neoplasms/surgery; Lymph Node Excision; Sigmoid Neoplasms \& Sigmoid Neoplasms/surgery.

\section{INTRODUCTION}

About 1.8 million new cases of colorectal cancer and 881,000 deaths were estimated to occur worldwide in 2018 (Bray et al., 2018), and about 12 million deaths per year, from this cause, will occur in 2030 (Itriago et al., 2013). The highest incidence rates are found in Australia, New Zealand, Europe and the United States; and the smallest in Western Africa and South-Central Asia (Ryerson et al., 2016). For example, in the USA, colorectal cancer represents the 4th most common cancer and the 2nd leading cause of cancer-related deaths (Siegel et al., 2019).

In Chile, the adjusted mortality rate for colon and rectal cancer in 2010, for women and men was 7.6 and $9.1 \mathrm{x}$ 100,000 inhabitants respectively; with an increase of 2 and 4 percentage points with respect to a similar measurement in 1990 (Itriago et al.).
Colon cancer (CC) standard treatment continues to be the resection of compromised colon segment with free margins (at least $5 \mathrm{~cm}$ above and below the tumor) and regional lymphadenectomy (by open or laparoscopic approach). These strategies could be associated or not, to complementary therapies (Athanasiou et al., 2017; Mungo et al., 2017).

Overall survival (OS) at 10 years in uncomplicated $\mathrm{CC}$, in stages I-III, operated with curative intention, ranges from $70 \%$ to $80 \%$ (Bannura et al., 2010; Qin et al., 2017); results that are better for most cancers of the digestive system. Therefore, postoperative morbidity (POM) and mortality of this type of patients must be rigorously controlled.

The aim of this study was to determine postoperative morbidity (POM) and 5-year overall survival (OS) in patients with uncomplicated colon cancer surgically treated.

\footnotetext{
${ }^{1}$ Department of Surgery and Center for Morphological and Surgical Studies (CEMyQ), Universidad de La Frontera, Temuco, Chile.

${ }^{2}$ Clínica Red Salud Mayor, Temuco, Chile.

${ }^{3}$ Hospital Obrero N ${ }^{\circ} 1$, Caja Nacional de Salud, La Paz, Bolivia.
} 


\section{MATERIAL AND METHOD}

The report of this study was written based on the MInCir Declaration for the reporting of descriptive observational studies (Manterola \& Otzen, 2017).

Study design: Case series with follow-up.

Setting: The study was conducted at Clínica Red Salud Mayor Temuco. The recruitment period was between January 2007 and December 2019 (13 years). The minimum followup was 12 months.

Participants: Patients operated for uncomplicated CC stages IIIa and IIIb, undergoing colectomy with lymph nodal dissection with oncological criteria; consecutively; in the period and institution indicated above, by the first author (CM). Palliative surgery cases and those who received neoadjuvant treatment were excluded.

Sample size: Since this is an observational and descriptive study, no sample size was estimated.

Variables: The outcome variables were overall survival (OS) and POM. The latter measured up to 30 days after surgery; it was considered dichotomous (present or absent); severity was estimated applying the Clavien-Dindo proposal (Clavien et al., 2009). Other variables of interest were age, sex, tumor location, stage of the disease (American Joint Committee on Cancer \& American College of Surgeons, 2018; Liu et al., 2018), type of surgery, operative mortality and recurrence.

Follow-up protocol: After hospital discharge, all patients were followed up with strict controls at least at months 1,2, 3 and 6; and after that once ayear. During the controls, a clinical evaluation, general laboratory tests and computed tomography of the abdomen and pelvis were realized. In addition, information on death certificates obtained from the Civil Registry and Identification was used, when necessary.

Statistical methods: Data collection was carried out and analyzed with the Stata 11.0 / SE® program. Descriptive statistics was used, applying measures of central tendency and dispersion (averages, standard deviations and extreme values). OS was calculated applying the Kaplan-Meier method and the comparison of curves was studied applying the log-rank test.

Biases: These were reduced with a masked data collection and a complete follow-up of the patients that make up this series for at least 6 months (the last patient recruited).
Ethics: Ethical guidelines for research defined by the Declaration of Helsinki (Helsinki Statement, 2013), were observed. All patients gave their informed consent in writing.

\section{RESULTS}

During the study period, 52 patients were operated for uncomplicated CC, with a median age of 68 (44-92) years, $53.8 \%$ were male. $88.5 \%$ of the series had some type of comorbidity (Table I).

Table I. Distribution of clinical variables in patients under study $(\mathrm{N}=52)$

\begin{tabular}{|c|c|c|}
\hline Variable & $\mathrm{N}^{\circ}$ cases & $\%$ \\
\hline \multicolumn{3}{|l|}{ Sex } \\
\hline Male & 28 & 53.8 \\
\hline Female & 24 & 46.2 \\
\hline \multicolumn{3}{|l|}{ Comorbidity } \\
\hline None & 6 & 11.5 \\
\hline AHT & 26 & 50.0 \\
\hline II-DM & 12 & 23.1 \\
\hline AHT + II-DM & 8 & 15.4 \\
\hline \multicolumn{3}{|l|}{ StageAMS } \\
\hline IIA & 6 & 11.5 \\
\hline IIIA & 19 & 36.6 \\
\hline IIIB & 22 & 42.3 \\
\hline IVA & 5 & 9.6 \\
\hline \multicolumn{3}{|l|}{ Tumoral location } \\
\hline Right colon & 22 & 42.3 \\
\hline Transverse colon & 4 & 7.7 \\
\hline Left colon & 12 & 23.1 \\
\hline Sigmoid colon & 14 & 26.9 \\
\hline \multicolumn{3}{|l|}{ Type of colectomy } \\
\hline Right colectomy & 22 & 42.3 \\
\hline Rightextended colectomy & 4 & 7.7 \\
\hline Left colectomy & 12 & 23.1 \\
\hline Sigmoidectomy & 14 & 26.9 \\
\hline
\end{tabular}

AHT:Arterial hypertension. II-DM:Type II diabetes mellitus. AMS: American Cancer Society.

The most frequent location of the lesions was: right colon (22 cases, $42.3 \%$ ) and sigmoid (14 cases, $26.9 \%$ ). The most frequent stage was IIIA and IIIB (78.9\%). With $100 \%$ resectability of the series, it was the right colectomy, the most frequently used technique (Figs. 1 and 2, Table I).

The medians of the surgical time, number of resected lymph nodes, and hospital stay were $98 \mathrm{~min}, 34$ resected lymph nodes and 4.5 days respectively (Table II).

POM was $17.3 \%$ (9 cases), most of which were Clavien \& Dindo Type I and II (5 cases, $55.6 \%$ ); 3 cases of 
anastomotic dehiscence stand out (5.8\%), all of which required reoperation (Table III). There was no operative mortality.

With a median follow-up of 58 months, a recurrence of $19.2 \%$ was verified (Table III). On the other hand, the 5year OS for stages IIA, IIIA, IIIB and IVA was $83.3 \%, 73.6$ $\%, 68.2 \%$ and $40 \%$ respectively ( $\mathrm{p}=0,001$ at months 30 , 48,54 and 60 , between stage IVa and the rest of stages) (Fig. 3).
Table II. Distribution of clinical variables in patients under study $(\mathrm{N}=52)$

\begin{tabular}{lcc}
\hline Variable & Median & $\begin{array}{c}\text { Minimum - } \\
\text { Maximum }\end{array}$ \\
\hline Age (years) & 68 & $44-92$ \\
BMI (kg/m $\mathrm{m}^{2}$ & 25,2 & $21-41$ \\
Symptom time (months) & 9 & $2-14$ \\
Surgical time (min) & 98 & $60-130$ \\
Preoperative CEA (ng/ml) & 112 & $3-540$ \\
Resected lymph nodes $\left(\mathrm{N}^{\circ}\right)$ & 34 & $25-45$ \\
Hospital stay (days) & 4.5 & $3-7$ \\
Follow-up (months) & 58 & $7-144$ \\
\hline
\end{tabular}

BMI: Body mass index. CEA: Carcinoembryonic antigen.

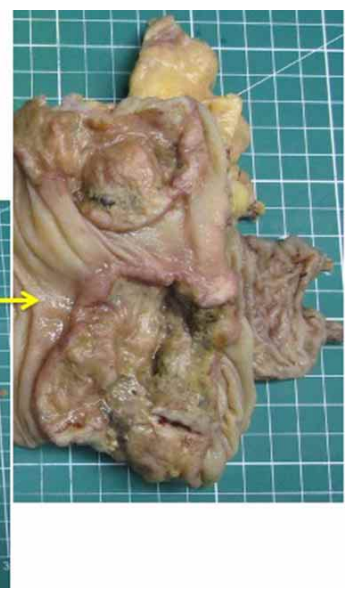

Fig. 1. Surgical specimen fixed and extended, corresponding to a patient with cancer of the cecum, $11 \mathrm{~cm}$ in diameter greater; discoidal, ulcerated; Infiltrating to subserous pericolonic fibroadipose tissue, with negative proximal, distal and mesocolonic edges (distance to the tumor: $6 ; 26.5$ and $9 \mathrm{~cm}$ respectively). Positive lymph nodes 1 out of 43 examined.
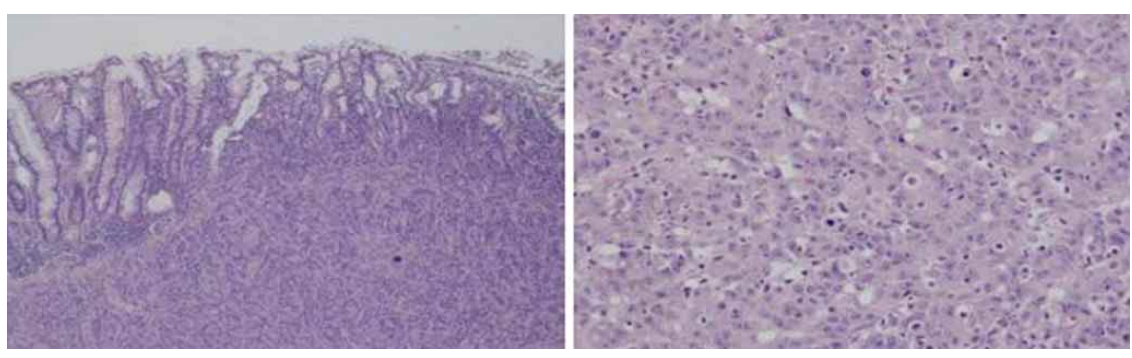

Fig. 2. Histological sections of a patient with right colon cancer. Histological type: poorly differentiated tubular adenocarcinoma; highgrade, with positive lymphovascular invasion.

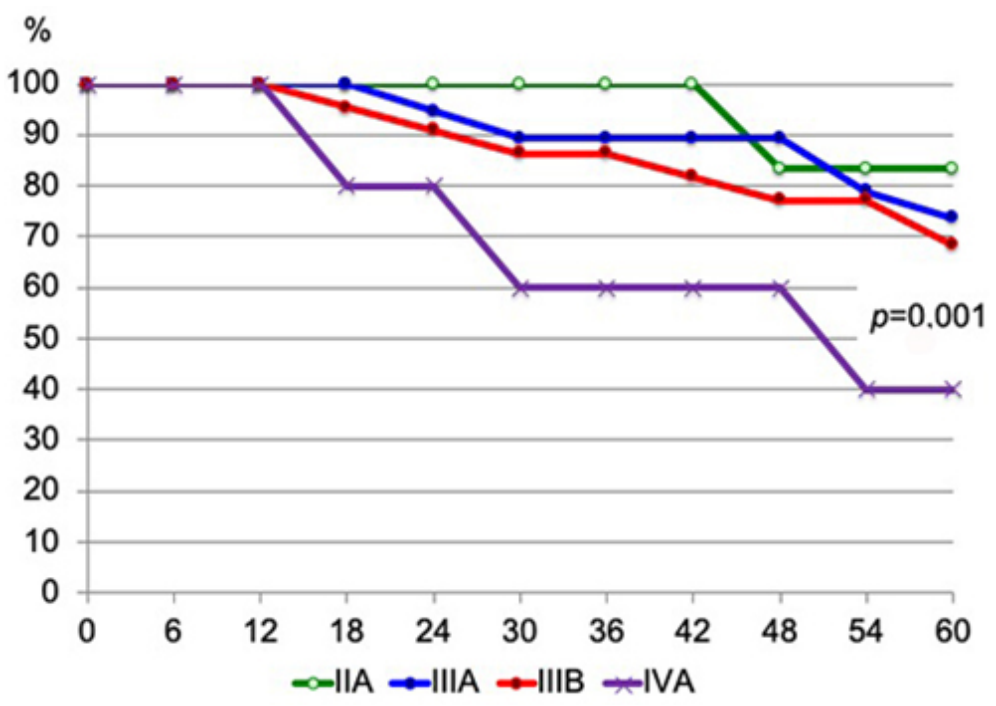

Fig. 3. Actuarial survival curve of the series (total and by stages).
Table III. Postoperative morbidityin patients under study $(\mathrm{N}=52)$.

\begin{tabular}{lcc}
\hline Variable & $\mathrm{N}^{\circ}$ cases & $\%$ \\
\hline POM & & \\
Present & 9 & 17.3 \\
Absent & 43 & 82.7 \\
POM etiology & & \\
Anastomotic leakage & 3 & 5.8 \\
Surgical site infection & 3 & 5.8 \\
$\quad$ Respiratory infection & 2 & 3.8 \\
$\quad$ Left ureteral injury $*$ & 1 & 1.9 \\
POM according Clavien & & \\
$\quad$ I & 3 & 5.8 \\
II & 2 & 3.8 \\
IIIb & 4 & 7.7 \\
Recurr ence & & \\
Yes & 10 & 19.2 \\
No & 42 & 80.8 \\
\hline
\end{tabular}

POM: Postoperative morbidity* : The ureteral injury was repaired in the course of the same intervention. 


\section{DISCUSSION}

Novelty of the proposal: The novelty of the proposal is that it is a single-center and regional casuistry of patients of a private health institution; with comparable results with different series from national and international referral centers (Bannura et al.; Renouf et al., 2013; Qin et al.). Generating evidence regarding results of CC surgery in a regional and private health center is relevant, since most of the series in our country correspond to public hospitals of the metropolitan area.

Comment on observed results: Surgery is essential in the treatment of CC and is considered curative when all macroscopic disease is removed, followed by the histological demonstration of the absence of neoplasia on the margins of the surgical specimen. Thus, $\mathrm{R} 0$ resection will be considered when in-block excision of the tumor with disease-free histological margins was performed (Liu et al.).

We observed that location of the primary lesions was mainly in the right colon (42.3\%). This is similar to previous reports (Bannura et al.; Tapia et al., 2010; Huang et al., 2016).

Regarding surgical techniques for $\mathrm{CC}$, there is no controversy. For example, in tumors of the transverse colon or hepatic angle the tendency is to perform extended right hemicolectomies. Special attention must be fixed on the surgical margins, since there is evidence in terms that the existence of a tumor in these margins is associated with up to $85 \%$ of recurrences (Merkel et al., 2016).

Iatrogenic perforation of the tumor during surgery is a significant factor because it conditions an increase in local recurrence (Maurer et al., 2017). This fact is independent of the stage and the degree of tumor fixation (Tokodai et al., 2016). We do not see this complication in our patients.

Although reports of surgical mortality for uncomplicated CC fluctuate between $1.5 \%$ and $9 \%$ (Kwaan et al., 2013; Healy et al., 2016; Mungo et al.), postoperative mortality was not recorded in this series.

POM of our series $(17.3 \%)$, is similar to other (Bannura et al.; Marinello et al., 2016). On the other hand, the reports regarding anastomotic filtration in elective colectomies, fluctuate between $6 \%$ and $9 \%$ (Ruggiero et al., 2011; Marinello et al.; García-Granero et al., 2017). This complication was verified in 3 cases $(5.8 \%)$.

The local recurrence was verified in $19.2 \%$ of cases, lower than reported after curative resection, which can reach
$31 \%$ (Alnimer et al., 2017). There is evidence that this is associated with vascular or lymphatic permeation to a number of resected lymph nodes less than 12 , as well as the type of resection (R1 and R2) (Kojo et al., 2017).

In relation to 5-year OS, our data $(83.3 \%, 73.6 \%$, $68.2 \%$ and $40 \%$ for stages IIA, IIIA, IIIB and IVA respectively), can be considered very suitable compared to what has already been published regarding uncomplicated $\mathrm{CC}$ without neoadjuvant treatments (Bannura et al.; Perdawid et al., 2012; Kwaan et al.; Renouf et al.). This may be due to the number of lymph nodes resected, because, there is evidence supporting that the resection of more than 12 lymph nodes, are associated with better survival, especially in stages IIA and IIIA; and in in right-sided CC (Huang et al.; Yang et al., 2018). Both characteristics were present in a many of our patients.

Limitations of the study: Among the limitations, it should be noted that this is a small series, in which all patients underwent surgery by the same surgeon. On the other hand, in the last cases, the follow-up is brief.

\section{CONCLUSIONS}

By way of conclusion, it can be stated that the results verified in this series, in terms of POM, mortality and 5year OS in patients with uncomplicated $\mathrm{CC}$, are comparable to national and international series in which neoadjuvant therapies have not been applied.

MANTEROLA, C.\& CLAROS, N. Resultados del tratamiento quirúrgico del cáncer de colon no complicado. Serie de casos con seguimiento. Int. J. Morphol., 39(4):1171-1175, 2021.

RESUMEN: El tratamiento estándar del cáncer de colon (CC), continua siendo la resección radical del segmento intestinal comprometido con márgenes libres (al menos $5 \mathrm{~cm}$ por encima y debajo del tumor), pudiendo asociarse o no a terapias complementarias. El objetivo de este estudio fue determinar morbilidad postoperatoria (MPO) y supervivencia actuarial global (SVAG) a 5 años en pacientes resecados por CC no complicado. Serie de casos con seguimiento, de pacientes con CC no complicado, sometidos a colectomía subtotal y linfadenectomía, de forma consecutiva, en Clínica Red Salud Mayor Temuco, entre 2007 y 2019. Las variables resultado fueron MPO y SV actuarial global (SVAG) a 5 años. Otras variables de interés fueron: tiempo quirúrgico, número de linfonodos resecados, estancia hospitalaria y recurrencia. Se utilizó estadística descriptiva, con medidas de tendencia central y dispersión; y análisis de SV con curvas de Kaplan Meier. Se intervinieron 52 pacientes $(53,8 \%$ hombres $)$, con una mediana de edad de 68 años. La localización y estadios más frecuentes fueron colon derecho (42,3\%); IIIA y IIIB respectivamente (78,9\%). La resecabilidad de la serie fue $100 \%$. La medianas del tiempo quirúrgico, del número 
de linfonodos resecados y de estancia hospitalaria; fueron de $98 \mathrm{~min}, 34$ y 4.5 días respectivamente. La MPO fue 17,3\% (9 casos). Con una mediana de seguimiento de 58 meses, se verificó una recurrencia de $19,2 \%$; y una SVAG a 5 años para los estadios IIA, IIIA, IIIB y IVA; de $83,3 \% ; 73,6 \% ; 68,2 \%$ y $40,0 \%$ respectivamente. Los resultados obtenidos, en términos de MPO, mortalidad y SVAG a 5 años, fueron similares a series de nacionales e internacionales.

PALABRAS CLAVE: Cáncer de colon; Cáncer de sigmoides; Linfadenectomía.

\section{REFERENCES}

Alnimer, Y.; Ghamrawi, R.; Aburahma, A.; Salah, S.; Rios-Bedoya, C. \& Katato, K. Factors associated with short recurrence-free survival in completely resected colon cancer. J. Community Hosp. Intern. Med. Perspect., 7(6):3416, 2017.

American Joint Committee on Cancer \& American College of Surgeons. AJCC Cancer Staging Form Supplement. 8th ed. Chicago, American Joint Committee on Cancer \& American College of Surgeons, 2018.

Athanasiou, C. D.; Robinson, J.; Yiasemidou, M.; Lockwood, S. \& Markides, G. A. Laparoscopic vs open approach for transverse colon cancer. A systematic review and meta-analysis of short and long term outcomes. Int. J. Surg., 41:78-85, 2017.

Bannura, G.; Cumsille, M.A.; Barrera, A.; Contreras, J.; Melo, C. \& Soto D. Resultados del tratamiento quirúrgico del cáncer de colon. Análisis de 439 pacientes. Rev. Chil. Cir., 62(5):491-6. 2010.

Bray, F.; Ferlay, J.; Soerjomataram, I.; Siegel, R. L.; Torre, L. A. \& Jemal, A. Global cancer statistics 2018: GLOBOCAN estimates of incidence and mortality worldwide for 36 cancers in 185 countries. CA Cancer J. Clin., 68(6):394-424, 2018.

Clavien, P. A; Barkun, J.; de Oliveira, M. L.; Vauthey, J. N.; Dindo, D.; Schulick, R. D.; de Santibañes, E.; Pekolj, J.; Slankamenac, K.; Bassi, C.; et al. The Clavien-Dindo classification of surgical complications: five-year experience. Ann. Surg., 250(2):187-96, 2009.

García-Granero, E.; Navarro, F.; Cerdán Santacruz, C.; Frasson, M.; García-Granero, A.; Marinello, F.; Flor-Lorente, B. \& Espí, A. Individual surgeon is an independent risk factor for leak after double-stapled colorectal anastomosis: An institutional analysis of 800 patients. Surgery, 162(5):1006-16, 2017.

Healy, M. A.; Grenda, T. R.; Suwanabol, P. A.; Yin, H.; Ghaferi, A. A.; Birkmeyer, J. D. \& Wong, S. L. Colon cancer operations at high- and low-mortality hospitals. Surgery, 160(2):359-65, 2016.

Helsinki Statement. WMA Declaration of Helsinki - Ethical Principles for Medical Research Involving Human Subjects. Fortaleza, 64th WMA General Assembly, 2013. Available from: https://www.wma.net/policies-post/ wma-declaration-of-helsinki-ethical-principles-for-medical-researchinvolving-human-subjects

Huang, B.; Feng, Y.; Ni, M.; Chen, C. \& Cai, G. Heterogeneous survival between stage IIA and stage IIIA colon cancer when different numbers of lymph nodes are harvested. ANZ J. Surg., 88(4):316-21, 2016.

Itriago, L.; Silva, N. \& Cortes, G. Epidemiology of cancer in Chile and worldwide: present and future. Rev. Med. Clin. Condes., 24(4):531-52, 2013.

Kojo, K.; Katoh, H.; Naito, M.; Yamashita, K.; Nakamura, T.; Sato, T.; Yamanashi, t. \& Watanabe, M. Lymphatic permeation predicts systemic recurrence in combination with vascular involvement in laparoscopically resected N0 colon cancer. Am. Surg., 83(12):1394-400, 2017.

Kwaan, J. R.; Al-Refaie, W. B.; Parsons, H. M.; Chow, C. J.; Rothenberger, D. A. \& Habermann, E. B. Are right-sided colectomy outcomes different from left-sided colectomy outcomes?: study of patients with colon cancer in the ACS NSQIP database. JAMA Surg., 148(6):504-10, 2013.

Liu, Q.; Luo, D.; Cai, S.; Li, Q. \& Li, X. P-TNM staging system for colon cancer: combination of P-stage and AJCC TNM staging system for improving prognostic prediction and clinical management. Cancer Manag Res., 10:2303-14, 2018.
Manterola, C. \& Otzen, P. Checklist for reporting results using observational descriptive studies as research designs. The MInCir initiative. Int. J. Morphol., 35(1):72-6, 2013.

Marinello, F. G.; Baguena, G.; Lucas, E.; Frasson, M.; Hervás, D.; Flor-Lorente, B.; Esclapez, P.; Espí, A. \& García-Granero, E. Anastomotic leakage after colon cancer resection: does the individual surgeon matter? Colorectal Dis., 18(6):562-9, 2016.

Maurer, C. A.; Dietrich, D.; Schilling, M. K.; Metzger, U.; Laffer, U.; Buchmann, P.; Lerf, B.; Villiger, P.; Melcher, G.; Klaiber, C.; et al. Prospective multicenter registration study of colorectal cancer: significant variations in radicality and oncosurgical quality-Swiss Group for Clinical Cancer Research Protocol SAKK 40/00. Int. J. Colorectal Dis., 32(1):57-74, 2017.

Merkel, S.; Weber, K.; Matzel, K.E.; Agaimy, A.; Göhl, J. \& Hohenberger, W. Prognosis of patients with colonic carcinoma before, during and after implementation of complete mesocolic excision. Br. J. Surg., 103(9):12209, 2016.

Mungo, B.; Papageorge, C. M.; Stem, M.; Molena, D. \& Lidor, A. O. The impact of operative approach on postoperative complications following colectomy for colon cancer. World J. Surg., 41(8):2143-52, 2017.

Perdawid, S. K.; Hemmingsen, L.; Boesby, S. \& Danish Colorectal Cancer Group. Survival after elective surgery for colonic cancer in Denmark. Colorectal Dis., 14(7):832-7, 2012.

Qin, Q.; Yang, L.; Sun, Y. K.; Ying, J. M.; Song, Y.; Zhang, W.; Wang, J. W. \& Zhou, A. P. Comparison of 627 patients with right- and left-sided colon cancer in China: Differences in clinicopathology, recurrence, and survival. Chronic Dis. Transl. Med., 3(1):51-9, 2017.

Renouf, D. J.; Woods, R.; Speers, C.; Hay, J.; Phang, P.T.; Fitzgerald, C. \& Kennecke, H. Improvements in 5-year outcomes of stage II/III rectal cancer relative to colon cancer. Am. J. Clin. Oncol., 36(6):558-64, 2013.

Ruggiero, R.; Sparavigna, L.; Docimo, G.; Gubitosi, A.; Agresti, M.; Procaccini, E. \& Docimo, L. Post-operative peritonitis due to anastomotic dehiscence after colonic resection. Multicentric experience, retrospective analysis of risk factors and review of the literatura. Ann. Ital. Chir., 82(5):369-75, 2011.

Ryerson, A. B.; Eheman, C. R.; Altekruse, S. F.; Ward, J. W.; Jemal, A.; Sherman, R. L.; Henley, S. J.; Holtzman, D.; Lake, A.; Noone, A. M.; et al. Annual Report to the Nation on the Status of Cancer, 1975-2012, featuring the increasing incidence of liver cancer. Cancer, 122(9):1312-37, 2016.

Siegel, R. L.; Miller, K. D. \& Jemal, A. Cancer statistics, 2019. CA Cancer J. Clin., 69(1):7-34, 2019.

Tapia, E. O.; Roa, S. J. C.; Manterola, D. C. \& Bellolio, J. E. Colon and rectum cancer: morphological and clinical description of 322 cases. Int. J. Morphol., 28(2):393-8, 2010

Tokodai, K.; Narimatsu, H.; Nishida, A.; Takaya, K.; Hara, Y.; Kawagishi, N.; Hashiyume, E. \& Ohuchi, N. Risk factors for recurrence in stage II/III colorectal cancer patients treated with curative surgery: The impact of postoperative tumor markers and an infiltrative growth pattern. J. Surg. Oncol., 114(3):368-74, 2016.

Yang, L.; Xiong, Z.; Xie, Q.; He, W.; Liu, S.; Kong, P.; Jiang, C.; Guo, G. \& Xia, L. Prognostic value of total number of lymph nodes retrieved differs between left-sided colon cancer and right-sided colon cancer in stage III patients with colon cancer. BMC Cancer, 18(1):558, 2018.

\section{Corresponding author: \\ Dr. Carlos Manterola \\ Department of Surgery and CEMyQ \\ Universidad de La Frontera \\ Temuco \\ CHILE}

E-mail: carlos.manterola@ufrontera.cl

Received: 16-03-2021

Accepted: 14-04-2021 